\title{
Scaffolding EARGD: On Effective Teaching Writing for EFL
}

\author{
Delfia Herwanis ${ }^{1, a}$, Barep Sarinauli1,, , Rahmanita Zakaria ${ }^{1, c}$, Emy Yusdiana ${ }^{1 \mathrm{~d}}$ \\ 1Department of English Education, Faculty of Education, State Institute of Islamic Studies Takengon, Aceh \\ Tengah, Indonesia \\ delfiaherwanis3@gmail.com; bbsnauli@yahoo.com; czrahmanita@gmail.com; emyyusdiana@gmail.com \\ *Corresponding Author: amadhania21@gmail.com | Phone Number: +6285372553186
}

\begin{abstract}
This paper is concerned with the applying scaffolding in learning of writing for English Second Language learners. A quantitative approach used to address the research problem in this paper. The subject is the second semester English Department students of IAIN Takengon, it was purposively sampled for the study. The pre- and post-test responses were evaluated using the same rubric, modified to evaluate students' writing content, to increase the reliability of the assessment. The same assessment given in the pre-test was used after the treatment. The assessment was used to determine whether students could demonstrate the application of new knowledge, language, and variation in organizational structure and whether scores had improved. The results have shown that the use of scaffolding EARGD is effective to increase students' writing ability.
\end{abstract}

Keywords: scaffolding; Effective; Teaching Writing; EFL

\section{Introduction}

Writing is one of the most difficult skills for most students and lecturers. Donn (1988) divided the problem that made writing difficult in three classifications. The first one is a linguistic difficulty. Language aspects such as vocabulary, grammar, use of language, and sentence choice in writing must be fully monitored. The second is the psychological difficulty, which focuses more on the difficulty of the writer because there is no direct interaction and feedback from the reader when they are writing. This difficulty focuses more on the difficulty of developing the material or content of the composition. The last is the cognitive difficulty. Writing has to be thought through formal instruction such as paragraphing, capitalization, spelling, and punctuation. Heaton (1975) said that writing skill is complex and sometimes it is difficult to teach. This research provides the solution to overcoming difficulties in teaching and learning writing to English Department students at Institut Agama Islam Negeri (IAIN) Takengon.

As far as the issue is concerned, an important guiding idea in education is the concepts of scaffolding and ZPD, as they provide a psycho-social model of teaching and learning. Tharp and Gallimore, though understanding the word scaffolding, prefer the notion of 'means of assisting'. Tharp and Gallimore (1991, p. 46) stated that "Teaching consists is about supporting performance through the ZPD, and it can be said to occur when assistance is obtainable at points within the ZPD where performance requires assistance". Reiser \& Tabak (2019) said the fundamental concept in scaffolding is that process is shared between the learner and some more experienced person or agent. Scaffolding not only facilitates the success of a task that is more challenging than the learner might manage on its own but also enhances learning from that experience.

In addition, the research needs to be carried out in order to determine the effectiveness of teaching techniques on student writing skills. The scaffolding in this study applied psycho-socio model which following some stages, there are: 1) A lecturer encourages (E) students; 2) Lecturer and student analyze (A) the text; 3) Rewrite (R) text and the lecturer guide (G) the students; 4) Discussion (D), these steps is abbreviated by EARGD. The formulation of the problem in this study is Does applying scaffolding EARGD effectively be used to increasing students' better writing ability?. 


\section{Literature Review}

\subsection{Scaffolding}

The term scaffolding was introduced by Wood, Bruner, \& Ross (1976), although never used by Vygotsky, in an attempt to operationalize the concept of teaching in the zone of proximal development (ZPD) (Wells, 1999). He defined scaffolding as "a way of operationalizing Vygotsky's (1987) concept of working in the zone of proximal development". There are three key features of particular character in educational scaffolding: 1) the basically dialogic nature of discourse whereabouts knowledge is co-constructed; 2) the connotation of the type of activity in which knowledge is embedded and 3) the artifacts can mediate knowing (Wells, 1999). The ZPD, defined as the distance between what a student can do with and without assistance (Vygotsky, 1978), is used to explain the social and participatory nature of teaching and learning. supporting children's active position in their learning and helping them to become self-regulated learners is at the heart of Vygotsky's concept of the ZPD.

In the socio-cultural educational theory, originated by Vygotsky (1978) the role of teacher-student contact in achievements of learners is strongly emphasized. Vygotsky said that a child follows the example an adult and eventually has the ability to perform those activities without help or assistance. The concept of ZPD by Vygotsky describes it as the distance between the actual level of development as determined by independent problem solving and the potential development as determined under adult supervision by problem solving or in partnership with more competent peers (Amiripour et al., 2012).

Scaffolding is a concept that resonates with the teacher. In the last 20 years or so, it has been taken up with passion and, while sometimes used loosely to refer to very different things, its popularity indicates that it captures sometimes used loosely to refer to very different things, its popularity indicates that it captures something which teachers perceive to be central to their core business - something at the heart of effective teaching (Hammond, 2001).

Besides the assistance which helps a learner accomplish a task, scaffolding will enable a learner to perform a task which they would not have been able to do on their own, and it is help that is supposed to bring the learner closer to a state of competence that would ultimately allow them to perform such a task on their own" (Webster, A, Beveridge, M \& Reed, 1996; Maybin, Mercer, \& Stierer, 1992).

The result of study Baradaran \& Sarfarazi (2011) is the students who had the chance to obtain scaffolding concepts outperformed those who did not experience scaffolding thereby having a significant impact on the academic writing of ESL students. In additional, some models are extremely effective for scaffolding are Inquiry, Modelling, Shared, Collaborative, Independent (IMSCI) to second language learners. The inquiry is first step, which encourages awareness of the background; the importance of which is as above. The teacher then models the formulation of the type of writing required after enabling prior information. Students and teacher then take part in shared writing, where the students have valuable input on the topic, sentence usage, etc. The opportunity then given to them to compose collaboratively with one or more other students to produce one piece of writing. The students are then ready for individual writing after completing the above steps, which is the ultimate aim of the scaffolding process (Read, 2010; Hsu et al., 2015; van der Valk \& de Jong, 2009).

As (Marcer, 1994) explains "scaffolding is the form and quality of cognitive support that an adult can provide for the learning of a child, which anticipates the internalization of mental functions by the child itself". The point here is that teachers are able to question and expand what students are able to do by sequencing teaching tasks, and by the consistency of their support and guidance, this is scaffolding means that refers to help designed to provide the required assistance to enable students to undertake tasks and establish understandings that they may not be able to handle on their own. Students are moved beyond their current abilities and levels of comprehension by engaging in such programs, and it is then that learning happens and students are able to 'internalize' new understandings.

\subsection{General Concept of Writing}

According to Rogers (2005), one of the most critical cultural accomplishments of the human beings is writing. It helps us, beyond the immediate moment, to document and communicate knowledge and stories. Raymond, J (2002) said in other words, that writing is also a way to find out what people know and what people need to understand. Writing requires process and experience to gain writing ability. Students who can write are those who also practice writing, so they can produce superior written text as a result. Brown (2004) notes that writing is the product of theories, concepts, principles, and improvement processes that involve require specialized knowledge that does not occur naturally. In the same way, Myles (2002) says that writing ability is a dynamic process involving the ability to interact in written form and create a text to effectively express a concept. 
Meanwhile in the context of an academic, writing ability is considered as an essential ability to obtain better results in continuing at a higher level in learning. The reason is supported by Nation (2009) who argues that one of the goals of student learning is to obtain superior talent in writing. According to him, this ability is very useful for students' careers going forward Writing is an important skill to learn for fieldwork and academic. The leaners must be able to include expertise in writing to generate good written content. They have to organize writing into cohesive and coherent paragraphs and texts (Barrass, 2005); (Dumais, 1988); (Ramlal \& Augustin, 2019); (Heaton, 1975); (Donn, 1988); (Oshima, Alice and Hogue, 2006); (Murray, Rowena and Moore, 2006); (Gordon, 2009); (Schumaker \& Lyerla, 1991). That is why the ability to write helps them to find what they need in the future, especially when they are searching for jobs and other things requiring writing expertise, irritability, guilt and depression.

Specifically, there are five elements of writing Mai (2016); Walker (2010); 1) Purpose, purpose statement is a short sentence that clearly defines the point of the paragraph. 2) The second element of good writing, the audience, is to have your audience in mind when you write. The word audience applies to the readers. Before they begin writing, good writers know who their audience is. As they write every sentence in their paragraph, good writers have their audience in mind. 3) Third element is clarity; clarity refers to how convenient the writing for the reader to understand. Good writers clearly illustrate their claims. Clear sentences are not ambiguous or indirect; they use descriptive, succinct language to get the point across to the reader. 4) Unity, unity in a paragraph implies that all the sentences are related to the topic sentence and its controlling idea. Good writers stay on topic by making sure that each supporting sentence relates to the topic sentence. 5) When all the concepts are arranged and flow seamlessly and logically from one to the next, a piece of writing has coherence. The reader will follow the key ideas more easily when a paragraph or essay has coherence.

\section{Materials and Methods}

The study used a quantitative approach to address the research problem by using numerical results, and the quantitative approach deals with quantifying and analyzing variables in order to get results (Apuke, 2017; Daniel, 2016; Petzer, 2016; Watson, 2015; Teo, 2014; Balnaves \& Caputi, 2011). The second semester English Department students of IAIN Takengon as subjects, it was purposively sampled for the study. Just one class consist of 16 students as Etikan (2016); (Tongco, 2007) stated that judgment sampling is deliberate choice of a participant due to qualities a participant process. Consideration of this case, so, all of the second-semester students as population and sample in this study. A pre-test was given to initiate the study, a writing assessment that was evaluated before the treatment began. This was used to ascertain students' general writing knowledge; content organization.

The test was based on a writing process rubric tool assessment and a universal type of rubric assessment. The same assessment given in the pre-test was used after the treatment. The assessment was used to determine whether students could demonstrate the application of new knowledge, language, and variation in organizational structure and whether scores had improved. Pre- and post-test responses were evaluated using the same rubric, modified to evaluate students' writing content, to increase the reliability of the assessment. Scores from the pre- and post-test were collected, compared, and analyzed to evaluate students' writing content. Both tests were scored out of the writing process rubric tool assessment and universal type rubric assessment. Raw scores from both tests were calculated to analyze variation between the pre-test scores to ascertain if the treatment had made any impact.

\section{Results and Discussions}

From the students' pre-test and post-test scores that shown the pre-test scores of 16 students improved after the treatment. In the pre-test the minimum scores were 2 , one student got an almost perfect score of 8 , three students got 3 scores, six students obtained 3 scores, two students obtained 5 marks, two students else obtained 6, 7 marks. While in the post-test one student improved his scores from 2 to 4 scores, one student increase from 2 to 5 scores, two students increased from 3 to 5 , one student improved from 3 to 6 , four students improved from 4 to 6 scores, two students improved from 4 to 7 scores, one student improved from 5 to 7 , one student from 5 to 8 , one student improved from 6 to 7 scores, one student improved from 7 to 9 scores, one student improved from 8 to 9 scores. The mean mark increased from 4 . 25 in the pre-test to a mean of 6.44 in the post-test, once again showing overall improvement.

At the start of the treatment, students were given formative writing assignments and the major issue highlighted were not following the writing process and the lack of writing qualities as shown in table 1 and table 2 as assignment tool in this study. Most students wrote one paragraph only and poor writing qualities. This can be compared after the researcher applied the scaffolding in teaching writing. Later formative writing assignments showed that the quantity of writing increased from one paragraph to an average of 
three paragraphs. Moreover, in the scaffolding process, many students such as Su.1, Su.6, Su.8, Su.10, and Su.14 were also significantly enhanced and organized each idea in distinct paragraphs, developing each idea fully and separately.

The dominant scaffolding applied to improve the students' practicing the writing process and revising the writing qualities was the lecturer guided them since the process of rewrite text. Students Su.6 for example has shown enthusiastic to pour her ideas into paragraphs. Su.11 and Su.13 provided their writing systematically and consistently.

According to Schirmer \& Bailey (2000), one of the popular assessment tools is the rubric. Based on predetermined criteria, student performance is assessed along several dimensions in a rubric. This study adapted the writing process rubric from (Schirmer \& Bailey, 2000, pp.56) as follow:

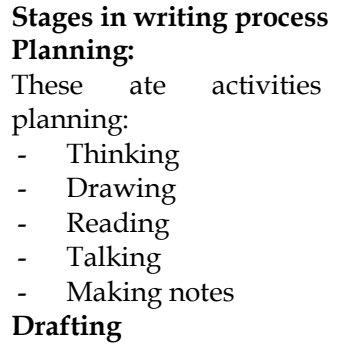

Revising

Editing
The studens did one activity and did it one time

The students wrote the whole piece without stopping
The students did more than one activity and I did it before writing and at least once during the writing

The students wrote a lot at one time and only stopped once or twice or plan or revise
The students did several activities and I did them before, during, and after writing
The students did not reread and did not change anything after wrote it.

The students did not fix the problems with spelling, punctuation, and grammar.
The students could not find very much change.

The students fixed a few of the problems with spelling, punctuation, and grammar.
Sometimes the students wrote a lot and sometimes the students wrote a lot and sometimes the students wrote a little beforw stopping. When they stopped, they evaluated, planned, or revised.

The students often reread what they had written and changed it because they were not satisfied.

The students used their editing check-list and fixed most of the problems with spelling, punctuation, and grammar.

The universal type rubric adapted from (Schirmer \& Bailey, 2000, pp. 54).

\begin{tabular}{|c|c|c|c|c|}
\hline Writing Qualities & 1 & 2 & 3 & 4 \\
\hline $\begin{array}{l}\text { Response to prompt/ } \\
\text { sequences }\end{array}$ & $\begin{array}{l}\text { Attempt to respond to } \\
\text { the prompt; unclear } \\
\text { sequence of events. }\end{array}$ & $\begin{array}{l}\text { An adequate response } \\
\text { to the prompt; sequence } \\
\text { may be unclear in many } \\
\text { places. }\end{array}$ & $\begin{array}{l}\text { Good response to the } \\
\text { prompt; sequence may } \\
\text { be entirely clear } \\
\text { through composition. } \\
\text { Good but may include }\end{array}$ & $\begin{array}{l}\text { Good response to the } \\
\text { prompt, introduced a } \\
\text { the beginning } \mathrm{o} \\
\text { composition; } \\
\text { sequence of events. }\end{array}$ \\
\hline Story Development & $\begin{array}{l}\text { Unclear or completely } \\
\text { lacking }\end{array}$ & $\begin{array}{l}\text { Adequate but includes } \\
\text { irrelevant or not } \\
\text { enough descriptions or } \\
\text { explanation }\end{array}$ & $\begin{array}{lr}\text { an } & \text { irrelevant } \\
\text { description } & \text { or } \\
\text { explanation } & \\
\text { Good but may include }\end{array}$ & $\begin{array}{l}\text { Clear with no irrelevan } \\
\text { descriptions } \\
\text { explanations. }\end{array}$ \\
\hline Organization & Nor described & Not completely clear & $\begin{array}{l}\text { too much emphasis on } \\
\text { one part composition. } \\
\text { Good but not }\end{array}$ & $\begin{array}{l}\text { Good: clear beginning } \\
\text { middle, and end. }\end{array}$ \\
\hline & & Adequate & $\begin{array}{l}\text { particularly fresh or } \\
\text { vivid. }\end{array}$ & Fresh and vigorous. \\
\hline Word choice & $\begin{array}{l}\text { Nonspecific } \\
\text { immature. }\end{array}$ & Few details & Sufficient details. & $\begin{array}{l}\text { Variety of interesting } \\
\text { details. }\end{array}$ \\
\hline Details & Lack of details & $\begin{array}{l}\text { Many incorrect and } \\
\text { inappropriate. }\end{array}$ & $\begin{array}{l}\text { Mostly correct and } \\
\text { appropriate. }\end{array}$ & $\begin{array}{lr}\text { Almost } & \text { completely } \\
\text { correct } & \text { anc } \\
\text { appropriate. } & \end{array}$ \\
\hline Sentence structures & $\begin{array}{l}\text { Incorrect and } \\
\text { inappropriate through } \\
\text { out composition }\end{array}$ & Serious errors & Some errors & Very few errors \\
\hline Mechanic & $\begin{array}{l}\text { Many } \\
\text { (punctuation, } \\
\text { capitalization, and } \\
\text { spelling). }\end{array}$ & & & \\
\hline
\end{tabular}


Procedure

The students are encouraged to compose their writing follow stages of the writing process, they are planning, drafting, revising, editing. They write about self-selected topics, and to determine whether a given composition will be completed and shared with an audience. In these stages, a lecturer relatively assists the students in practicing the stages of writing by using construction, so that the students know how to do something and will be able to complete a similar task alone. The teacher can focus on all aspects of writing when joint construction. It offers opportunities for both teachers and students to analyze the overall text structure, recommends more suitable vocabulary, finds alternate ways of expressing a concept, and focuses on using proper grammar, spelling, and punctuation. The lecturer works collaboratively with them to create the text. When this first draft has been written, the lecturer or a student can rewrite it on a large sheet of paper or replicate it electronically so that it subsequent model text students can access it as they progress towards writing themselves.

In this study, the position of a lecturer is a kind of editor; she takes up the ideas of the students, leading the discussion of any linguistic aspects of the text that students are still learning to manage and explain the vague wording. A tool for both lecturers and students to reflect on how language is used is meta-language (a language about language) explicitly. This is intended to encourage students to think more holistically about their writing and allows a lecturer to give more explicit feedback to children about their writing. The procedure of learning adapted from (Gibbons, 2015, pp. 119-120). follow:

All of the stages of teaching-learning above describe the psycho-social model of scaffolding is running as

1. A lecturer encourages (E) students

2. Lecturer and student analyze $(\mathrm{A})$ the text

3. Rewrite $(\mathrm{R})$ text and the lecturer guide $(\mathrm{G})$ the students

4. Discussion (D)

\section{Conclusion}

The effective use of scaffolding EARGD was illustrated in the writing learning process by following the students' abilities to progress at each stage. Each student increases her/ his ability following the writing process that is accompanied by a lecturer in every step. The results have shown that the use of scaffolding EARGD is effective to increase students' writing ability. Meaning that pursuing the students' abilities progress and providing assistance to each stage is an urgent thing to do in the implementation of scaffolding in this study.

By performing several activity loops, the lecturer applies these techniques. The lecturer begins the activity first by saying Basmallah, salam, and praying, and checking the attendance of the students. The next steps is encourage (E). This step aimed to motivate the students and help them in getting the ideas and flour their writing into piece of paper until each of them produced their writing. After each of student finished write their idea into piece of paper, the lecturer analyze (A) it and support students to correct their writing so rewrite (R) and in this process, the lecturer directly guide (G) the students until they understand why their writing need to be revised and where the error lies, so, discuss (D) it with students.

\section{Acknowledgement}

The author wishes to express her sincerest gratitude and warm appreciation to the following had contributed much in helping her shape and reshape this article. Dr. Zulkarnain, M. Ag as chairman of the State Institute of Islamic Religion and Dr. Al Musanna, M. Ag as the Vice chairman of the State Institute of Islamic Religion for their necessary suggestions to better this article or this study.

\section{Author's Contributions}

The problem and methodology come from first author., so second until fourth authors discussed the results and contributed to from the start to final manuscript, besides that, the first author as correspondence also.

\section{Conflict of Interest}

The authors declare that they have no competing interests. 


\section{References}

Amiripour, P., Amir-Mofidi, S., \& Shahvarani, A. (2012). Scaffolding as effective method for mathematical learning. Indian Journal of Science and Technology. https://doi.org/10.17485/ijst/2012/v5i9/30681

Apuke, O. (2017). Quantitative Research Methods: A Synopsis Approach. Arabian Journal of Business and Management Review (Kuwait Chapter)., 6, 40-47. https:// doi.org/10.12816/0040336

Balnaves, M., \& Caputi, P. (2011). Introduction to Quantitative Research Methods. In Introduction to Quantitative Research Methods (Issue October). https:// doi.org/10.4135/9781849209380

Baradaran, A., \& Sarfarazi, B. (2011). The impact of scaffolding on the iranian EFL learners' english academic writing. Australian Journal of Basic and Applied Sciences, 5(12), 2265-2273.

Barrass, R. (2005). Students Must Write: A Guide to Better Writing in Coursework and Examinations. In Reading. http://www.amazon.co.uk/dp/0415358264

Brown, H. D. (2004). Language assessment: principles and classroom practices. Longman.

Daniel, E. (2016). The Usefulness of Qualitative and Quantitative Approaches and Methods in Researching Problem-Solving Ability in Science Education Curriculum. Journal of Education and Practice, 7(15), 91100. https://doi.org/2222-288X

Donn, B. (1988). Teaching Writing Skill. Longman Group UK limited.

Dumais, W. (1988). Writing in English. Departemen Pendidikan dan Kebudayaan.

Etikan, I. (2016). Comparison of Convenience Sampling and Purposive Sampling. American Journal of Theoretical and Applied Statistics, 5(1), 1. https://doi.org/10.11648/j.ajtas.20160501.11

Gibbons, P. (2015). Scaffolding language, scaffolding learning (H. . Price (Ed.); Second). Heinemann.

Gordon, L. (2009). Writing and good language learners. In Lessons from Good Language Learners. https:// doi.org/10.1017/cbo9780511497667.022

Hammond, J. (2001). Scaffolding: Teaching and Learning in Language and Literacy Education. In Primary English Teaching Assoc. https://doi.org/10.1007/s13398-014-0173-7.2

Heaton, J. (1975). Writing English Language Texts. Longman.

Hsu, Y. S., Lai, T. L., \& Hsu, W. H. (2015). A Design Model of Distributed Scaffolding for Inquiry-Based Learning. Research in Science Education. https://doi.org/10.1007/s11165-014-9421-2

Mai, C. (2016). Five Elements of Good Writing. 40-56.

Marcer, N. (1994). Neo Vygotskian Theory and Classroom Education In Sterier, B \& Maybin, J (eds). Language, Literacy and Learning in Educational Practice, Multilingual Matters, Clevedon, UK.

Maybin, J., Mercer, N., \& Stierer, B. (1992). Reading 7 ' Scaffolding ' learning in the classroom. Thinking Voices: Work of the National Oracy Project.

Murray, Rowena and Moore, S. (2006). The Handbook of Academic Writing. Open University Press.

Myles, J. (2002). TESL-EJ : teaching English as a second or foreign language. TESL-EJ.

Nation, I. S. P. (2009). Teaching ESL/EFL listening and speaking. Routledge Taylor \& Francis Group.

Oshima, Alice and Hogue, A. (2006). Writing Academic Writing. Pearson Longman.

Petzer, D. (2016). Quantitative Research Module. Doctoral Programme 2016, 1-16.

Ramlal, A., \& Augustin, D. S. (2019). Engaging students in reflective writing: an action research project. Educational Action Research, 00(00), 1-16. https://doi.org/10.1080/09650792.2019.1595079

Raymond, J, C. (2002). Writing (Is Unnatural Act). Harper \& Row.

Read, S. (2010). A Model for Scaffolding Writing Instruction: IMSCI. The Reading Teacher. https://doi.org/10.1598/rt.64.1.5

Reiser, B. J., \& Tabak, I. (2019). Scaffolding. 44-62.

Rogers, H. (2005). A Linguistic Approach. Blackwell.

Schirmer, B. R., \& Bailey, J. (2000). Writing Assessment Rubric. TEACHING Exceptional Children, 33(1), 52-58. https://doi.org/10.1177/004005990003300110

Schumaker, J. B., \& Lyerla, K. D. (1991). The paragraph writing strategy.

Teo, T. (2014). Handbook of quantitative methods for educational research: Springer Science \& Business Media. http://web.b.ebscohost.com/ehost/ebookviewer/ebook/bmxlYmtfXzcwNjg1NV9fQU41?sid=4a6585 4e-4284-4144-a044-283db67e5236@sessionmgr120\&vid=3\&format=EB\&rid=10

Tharp, R. G., \& Gallimore, R. (1991). Rousing Minds to Life: Teaching, Learning, and Schooling in Social Context. Educational Researcher, 21(5), 31. https://doi.org/10.2307/1176847

Tongco, M. D. C. (2007). Purposive sampling as a tool for informant selection. Ethnobotany Research and Applications, 5, 147-158. https://doi.org/10.17348/era.5.0.147-158

van der Valk, T., \& de Jong, O. (2009). Scaffolding science teachers in open-inquiry teaching. International Journal of Science Education. https://doi.org/10.1080/09500690802287155

Vygotsky, L. (1978). Mind in society. Harvard University Press. 
Vygotsky, L. S. (1978). Mind in Society (E. Cole, M., Steiner, V.J., Scribner, S., Souberman (Ed.)). Harvard University Press. https://doi.org/10.4244/EIJY14M06_06

Walker, R. (2010). Five Elements of Good Writing. 1-26.

Watson, R. (2015). Quantitative research. In Nursing standard (Royal College of Nursing (Great Britain) : 1987) (Vol. 29, Issue 31). https:// doi.org/10.7748/ns.29.31.44.e8681

Webster, A, Beveridge, M \& Reed, M. (1996). Managing the Literacy Curriculum. Routledge.

Wells, G. (1999). Dialogic inquiry: Towards a sociocultural practice and theory of education. Cambridge University Press.

Wood, D., Bruner, J. S., \& Ross, G. (1976). the Role of Tutoring in Problem Solving. Journal of Child Psychology and Psychiatry, 17(2), 89-100. https://doi.org/10.1111/j.1469-7610.1976.tb00381.x 